\title{
In vitro AND in situ DIGESTIBILITY OF ANNUAL RYEGRASS SILAGE FROM DISTINCT PHENOLOGICAL GROWTH STAGES AND PRE- DEHYDRATION TIMES
}

\author{
DIGESTIBILIDADE IN VITRO E IN SITU DE SILAGEM DE AZEVÉM ANUAL \\ ORIUNDA DE DIFERENTES ESTÁDIOS FENOLÓGICOS E TEMPOS DE PRÉ- \\ SECAGEM
}

\author{
Ana Carolina FLUCK ${ }^{1}$; Olmar Antônio Denardin COSTA ${ }^{1}$; Jorge SCHAFHAUSER JUNIOR ${ }^{2}$; \\ Patrícia Pinto da ROSA $^{1}$; Leila CARDOZO ${ }^{1}$; Rudolf Brand SCHEIBLER ${ }^{1}$; \\ Fábio Antunes RIZZO ${ }^{1}$; Hero ALFAYA JUNIOR ${ }^{1}$ \\ 1. Universidade Federal de Pelotas - UFPEL, Pelotas, RS, Brasil. 2. Embrapa Clima Temperado; Pelotas, RS, Brasil
}

\begin{abstract}
The aim was to evaluate how the fodder pre- dehydration time and its phenological stages influence on ruminal degradability and digestibility of ryegrass silage. The evaluated samples consisted of treatments: Vegetative: Cut and ensiled; cut +4 hours pre-drying and ensiled and; cut +7 hours pre-drying and ensiled; Pre-flowering: Silage cutting and ensiled and 4 hours pre-drying and ensiled; Flowering: cut and ensiled, no pre-drying, with four replications each treatment. Silage was storage for four months. It was carried out three in situ digestibility assays to determine the curve of ruminal degradability at different times (3, 6, 9, 12, 24, 48 and 72 hours), like in situ digestibility and other three assays of 24 hours and 48 hours to determinate in vitro digestibility of silage. The digestibility of ryegrass silage was influenced by both the pre-dehydration times and phenological stage, and the dehydration time of cut and silage had a high proportion of degradable components, with higher degradation rate by 24 hours of incubation. The in vitro digestibility of the ryegrass silage was greater than that in situ for up to 48 hours. The digestibility of the ensiled ryegrass biomass was influenced by the dehydration times, as well as the plant growth stage, regardless of the methodology used, being higher values for the treatment without previous drying of the vegetative stage.
\end{abstract}

KEYWORDS: Lolium multiflorum. Pre-dried silage. Ruminal degradation. Ruminant Nutrition. Winter fodder.

\section{INTRODUCTION}

An increasing advance of agricultural frontiers and the competition for agricultural areas has required the intensification of livestock production systems (ANTLE et al., 2017), mostly in developing countries. Into this backdrop, in order to keep beef and dairy farming competitive, it is essential to increase the profitability of these systems. For it, one of the main determinants of a great productive performance is related to the quantity and quality of bulky feed offered.

In temperate and subtropical regions, even in tropical regions of altitude, ryegrass can show an important alternative for maintaining ruminants throughput, mostly due to its nutritional quality (WILKINS; HUMPREY, 2003; ROMAN et al., 2010).

Due to its proven nutritional quality (SKONIESKI et al., 2011; MARCHESAN et al., 2015), ryegrass emerges as an alternative to be used in ruminant nutrition as well as preserved fodder. One of the main tools used to keep the forage productive and qualitative constancy used in ruminant nutrition is the silage process. Firstly, described as an alternative for the conservation of forages for use in times of shortage, it is straightaway part of the food base of more modernized herds, being used without interruption.

The production of silage with winter grasses is a challenge that has been studied in temperate countries, especially in ratio to the physiological stage most suitable for silage. Several studies have been carried out demonstrating the efficacy of ryegrass, both as a feed base in the winter period of livestock systems, as its applicability and characteristics, however, there are few studies that characterize the quality and efficiency of conservation methods such as silage. Conversely, Schmidt et al. (2014) reported that the ensiling of forage with a moisture content of $70 \%$ or more will cause qualitative losses of the material. Because of these high moisture contents in their vegetative stage, it is crucial to know the best time to ensilage without losing its nutritional characteristics, avoiding loss of quality (KUNG, 2002) and how it will impact on ruminal degradation.

Usually, in vivo assays are carried out to predict feed digestibility for ruminants, however, it requires a long time to obtain results, besides 
relatively high costs with animals, feeding, housing, laboratory analysis and allows the evaluation of a limited number of feed in each assay (SILVEIRA et al., 2009). By contrast, laboratorial methodologies, with significantly lower costs and time, were developed to estimate the digestibility of food at ruminal level, in situ and in vitro digestibility. Thus, the aim was to determine the ruminal degradability curve, by in situ technique, of ryegrass silage at different phenological stages and different times of dehydration of biomass, as its ruminal in vitro and in situ digestibility at predetermined distinct predrying times.

\section{MATERIAL AND METHODS}

\section{Local description:}

All the assays (field and laboratory evaluation) from this study was conducted at Embrapa Clima Temperado-Estação Terras Baixas, located in Capão do Leão (31॰52' 20' $\mathrm{S}$ and $52^{\circ} 21^{\prime}$ 24" W), Rio Grande do Sul, Brazil., RS; from April 2013 to March 2015.

\section{Treatments and chemical characterization:}

For both assays, we used samples of annual ryegrass silage cv. BRS Ponteio, obtained at different phenological stages and submitted or not to the previous drying. After the establishment of pasture, it were made $7 \mathrm{~cm}$ cutting height, into the three plant phenological phases: vegetative, three different drying periods where determined (cut and ensile as such, cut and pre-drying of 4 hours and ensile, cut and a pre drying of 7 hours for ensiling); for the pre flowering phase to drying times were determined (ensiling just after cutting and a pre drying of 4 hours) and at full flowering, due to its low humidity content, there was no pre drying. Experimental design was a randomized blocks with six treatments and four repetitions. To fill up the micro-silos, ryegrass was cut to $5 \mathrm{~cm}$ long stubs and ensiled in PVC experimental micro-silos with dry matter density of $650 \mathrm{~kg} \mathrm{~m}^{-3}$, at all stages, and 4 months stored. When opened, sub samples were taken for the chemical compositions and digestibility evaluations. Samples were dried at a forced-air dryer at $55{ }^{\circ} \mathrm{C}$, for 72 hours and were ground, in Wiley mill type, to pass a 1-mm sieve for in vitro and 2-mm sieve for in situ.

Chemical characterization (Table 1) included: dry matter (DM; Method 967.03; AOAC, 1998); ash content by combustion in muffle furnace $\left(550^{\circ} \mathrm{C}, 4 \mathrm{hs}\right)$; organic matter $(\mathrm{OM})$, estimated by equation 100 - ash (Method 942.05; AOAC, 1998); crude protein (CP; Method 984.13; AOAC, 1997); neutral detergent fiber (NDF) and acid detergent fiber (ADF) determination as describe for Van Soest et al. (1991), adjusted to Senger et al. (2008), using $16 \mu \mathrm{m}$ polyester bags and $110^{\circ} \mathrm{C}$ autoclave during $40 \mathrm{~min}$ and acid detergent lignin (ADL), by $12 \mathrm{M}$ sulfuric acid treatment on ADF residue (Method 973.18; AOAC, 1998). Hemicellulose was estimated as the difference between NDF and ADF, and cellulose as the difference between ADF and ADL (VAN SOEST et al., 1991).

Table 1. Chemical composition of annual ryegrass silage* originated from different times of dehydration and different phenological stages.

\begin{tabular}{ccccccc}
\hline $\begin{array}{c}\text { Phenological stage } \\
\text { Dehydration times }\end{array}$ & 0 & 4 & 7 & 0 & 4 & 0 \\
\hline DM $\left(\mathrm{g} \mathrm{kg}^{-1}\right.$ wet $)$ & $138 \pm 4.8$ & $251 \pm 3.5$ & $293 \pm 14.2$ & $233 \pm 4.3$ & $292 \pm 10.2$ & $445 \pm 9.7$ \\
\hline Composition $\left(\mathrm{g} \mathrm{kg}^{-1} \mathrm{DM}\right)$ & & & & & & \\
\hline OM & $891 \pm 2.1$ & $899 \pm 5.9$ & $899 \pm 3.9$ & $893 \pm 7.9$ & $901 \pm 7.1$ & $924 \pm 8.8$ \\
CP & $178 \pm 6.3$ & $162 \pm 8.2$ & $152 \pm 10.7$ & $113 \pm 3.9$ & $110 \pm 6.7$ & $780 \pm 2.1$ \\
NDF & $367 \pm 6.9$ & $369 \pm 9.7$ & $382 \pm 11.7$ & $398 \pm 15.2$ & $425 \pm 4.5$ & $535 \pm 21.1$ \\
Hemicellulose & $135 \pm 9.1$ & $148 \pm 8.9$ & $159 \pm 2.6$ & $159 \pm 6.3$ & $177 \pm 9.4$ & $185 \pm 8.05$ \\
ADF & $233 \pm 2.4$ & $218 \pm 4.9$ & $236 \pm 12.5$ & $238 \pm 15.8$ & $248 \pm 12.1$ & $349 \pm 18.4$ \\
Cellulose & $193 \pm 2.2$ & $179 \pm 4.9$ & $181 \pm 11.7$ & $184 \pm 13.2$ & $191 \pm 13.1$ & $267 \pm 20.4$ \\
ADL & $40 \pm 0.7$ & $43 \pm 4.74$ & $43 \pm 1.2$ & $53 \pm 3.4$ & $57 \pm 1.3$ & $82 \pm 3.7$ \\
\hline
\end{tabular}

* Ryegrass was cut at $5 \mathrm{~cm}$ residue when the swards reached a height of $30 \mathrm{~cm}$ at each phenological stage. Values are means \pm S.e. of samples taken throughout experimental micro-silos $(n=4)$. 


\section{In vitro and in situ evaluations}

All surgical and animal care protocols were approved by the Ethics Committee on Animal Research from Universidade Federal de Pelotas (CEEA $\left.n^{\circ} 5076-2013\right)$. Three in vitro digestibility assays were carried out for 48 or $24 \mathrm{~h}$, using the method adapted from Goering and Van Soest (1970). For the incubation medium, aliquots of ruminal fluid were collected from four cannulated Jersey cows, fed a diet comprised by Axonopus affinis and Paspalum notatum and $1 \mathrm{~kg} \mathrm{day}^{-1}$ of ground corn.

After gathering, ruminal liquid was filtered through two layers cheesecloth, keeping up $39^{\circ} \mathrm{C}$, while constantly purged $\mathrm{CO}_{2}$. A total of $400 \mathrm{~mL}$ of the filtered rumen fluid was poured into the incubation jar that contained $1600 \mathrm{~mL}$ of buffer $\left(\mathrm{KH}_{2} \mathrm{PO}_{4}, 8.3 \mathrm{~g} \mathrm{~L}^{-1}, \mathrm{MgSO}_{4} * 7 \mathrm{H}_{2} \mathrm{O}, 0.41 \mathrm{~g} \mathrm{~L}^{-1}, \mathrm{NaCl}\right.$, $0.41 \mathrm{~g} \mathrm{~L}^{-1}, \mathrm{CaCl}_{2} * 2 \mathrm{H}_{2} \mathrm{O}, 0.08 \mathrm{~g} \mathrm{~L}^{-1}$, urea $0.41 \mathrm{~g} \mathrm{~L}^{-1}$, $\mathrm{Na}_{2} \mathrm{CO}_{3}, 2.5 \mathrm{~g} \mathrm{~L}^{-1}$ and $\mathrm{Na}_{2} \mathrm{~S}^{*} 9 \mathrm{H}_{2} \mathrm{O}, 0.16 \mathrm{~g} \mathrm{~L}^{-1}$ ), sustained 1:4 rumen fluid:buffer ratio. Samples were alocated into polyester $40 \mu \mathrm{m}$ bags (i.e. equal an $1 \mathrm{~g}$ sample $100 \mathrm{~mL}^{-1}$ incubation medium) and the digestibility technique applied for the estimation of in vitro true digestibility (IVTD) was the ruminal fermentor methodology for 48 or 24 hours unremitting at in vitro fermentor TE-150 Tecnal ${ }_{\text {, }}$ controlled by a thermostat. DM IVTD was estimate by calculation NDF residue content post incubation and in vitro DM (IVDM) and in vitro OM (IVOM) disappearance was estimate from the incubation residue.

Three in situ degradability were also carried out on the same four Jersey cows used for in vitro assay ruminal fluid collections $(4585 \pm 34.2 \mathrm{~kg}$ live weight) grazed on grass (Axonopus affinis and Paspalum notatum). Samples of approximately $1 \mathrm{~g}$ DM were placed in polyester bags $(5 \times 5 \mathrm{~cm}$; pore size of $40 \mu \mathrm{m}$; sample:bag as $\pm 15 \mathrm{mg} \mathrm{cm}^{-2}$ ) and sealed were rumen incubated for $3 ; 6 ; 9 ; 12 ; 24 ; 48$ and 72 hours using a gradual in/all out sequence, incubated into duplicate in each animal. Polyester bags were allocated into laundry bags $(25 \times 40 \mathrm{~cm})$ and after were placed within three polyester laundry bags $(30 \times 40 \mathrm{~cm})$ to ensure similar location within the rumen and to facilitate location for removal (VANZANT et al., 1996) and placed in ventral sac of the rumen. All treatments were incubated in each animal (6 treatments $\times 7$ incubation times $\times 4$ replicates $\times 4$ animals) and the assay three times replicated.

Subsequently removal, all bags were washed in flowing water until the water pour clear. Then, samples were submerged for 15 minutes in a bacterial dissociation solution to eliminate any microbial contamination, washed, oven-dried at 105 ${ }^{\circ} \mathrm{C}$ for 8 hours, and weighed. The 24, 48 and 72 hours residue was treated at same process with neutral detergent previously describe. In situ digestibility was estimate by difference between means of sample disappearance for each treatment (with or no NDS procedure) in its respective incubation times and values of the DM incubated.

\section{Statistical procedures}

Data were analyzed using mixed procedure of SAS 9.0 (SAS Inst., Inc., Cary, NC) by analysis of variance and means compared by DMS Fisher's Test $(\mathrm{P}<0.05)$. When interaction observed for total digestibility, means were compared by Student $t$ Test. Ruminal degradability data, after analysis of variance, were submitted to polynomial regression analysis.

\section{RESULTS AND DISCUSSION}

For in vitro assay (Table 2), we observed negative effects $(\mathrm{P}<0.05)$ both related to the phenological stage and pre-dehydration time, independent of incubation time $(24 ; 48 \mathrm{~h})$ for all parameters evaluated. Velásquez et al. (2010) discussed that minimization on digestibility with the plant development growth cycle is widely discussed, due to the accretion of structural carbohydrates and cellular content decreased. Another factor to be considered is that this process also contributed to the rate of cell wall degradation, as long as a much larger fraction of the compounds are degraded in the first 24 hours on silage of young plants, howsoever, this is not repeated in plants at the end of productive cycle, substantiate what was found in this study.

Also, was verified negative correlation between DM IVTD and ryegrass silage contents of: NDF $(\mathrm{P}<0.0001, \mathrm{R}=-0.92)$, ADF $(\mathrm{P}<0.0001, \mathrm{R}=-$ $0.87)$ and $\mathrm{ADL}(\mathrm{P}<0.0001, \mathrm{R}=-0.94)$ Additionally, $\mathrm{CP}$ showed high positive correlation $(\mathrm{P}<0.0001$, $\mathrm{R}=0.92$ ).

Distinct authors (MARTINS et al., 2006; MACEDO JÚNIOR et al., 2007; SANTOS et al., 2011) reported that the increase of structural carbohydrates occurs parallel to the increase in lignin contents, phenolic component that limits and extension of the fibrous digestion in the rumen, being consistent with those reported in the present research. Lignification restricts the performance of digestive enzymes produced by rumen microorganisms and, hence, decreases digestibility. Additionally, Balsalobre et al. (2003) emphasize that the variation in the fibrous fraction quality interferes directly in energy availability for 
ruminant, thereby, progress in plant growth cycle causes increase in the constituents of the cell wall, Thus, reducing the levels of non-fibrous carbohydrates hence lower energy of rapid degradation for ruminal microorganisms, reducing the capacity to be digested.

Table 2. In vitro dry matter and organic matter disappearance and in vitro dry matter true digestibility at 24 and 48 hours of incubation of annual ryegrass at distinct phenological growth stages and pre- dehydration times.

\begin{tabular}{lcccccccccc}
\hline & \multicolumn{9}{c}{ Vegetative } & \multicolumn{7}{c}{ Pre-Flowering } & Flowering & SEM & \multirow{2}{*}{$\mathrm{R}^{2}$} & P value \\
\cline { 2 - 9 } & 0 & 4 & 7 & 0 & 4 & 0 & & & \\
\hline 24 h incubation & & & & & & & & & \\
\hline DM disappearance & 43.44 & 42.03 & 41.02 & 32.73 & 31.33 & 24.58 & 2.11 & 0.92 & $<0.0001$ \\
OM disappearance & 48.75 & 46.76 & 45.63 & 36.65 & 34.78 & 26.60 & 2.43 & 0.92 & $<0.0001$ \\
DM IVTD & 50.22 & 48.16 & 47.00 & 37.75 & 35.82 & 27.40 & 2.41 & 0.92 & $<0.0001$ \\
\hline 48 h incubation & & & & & & & & & \\
\hline DM disappearance & 66.62 & 63.78 & 60.82 & 58.76 & 53.62 & 44.68 & 0.88 & 0.98 & $<0.0001$ \\
OM disappearance & 72.53 & 68.81 & 65.63 & 63.83 & 57.73 & 46.9 & 0.95 & 0.98 & $<0.0001$ \\
DM IVTD & 74.78 & 70.94 & 67.66 & 65.80 & 59.51 & 48.35 & 0.98 & 0.98 & $<0.0001$ \\
\hline
\end{tabular}

SEM: Standard error mean; $\mathrm{R}^{2}$ :coefficient of determination. $P$ value: 0.05

We observed a linear effect $(\mathrm{P}<0.05)$ under the influence of dehydration for in situ (table 3), as like was found for in vitro, where the digestibility was negatively affected as the time, as well the phonological stage. According to this evidence, we concluded that after the plant harvest, the process of degradation of the soluble carbohydrates begins with the cellular respiration. This decreases the faster degradable fraction of plant, directly influencing the digestibility of the material, more evidenced in the vegetative stage.

Table 3. In situ digestibility of annual ryegrass silage at distinct phenological growth stages and predehydration times.

\begin{tabular}{|c|c|c|c|c|c|c|}
\hline \multirow[b]{2}{*}{$\begin{array}{l}\text { Phenological } \\
\text { Stage }\end{array}$} & \multirow[b]{2}{*}{$\begin{array}{c}\text { Pre- dehydration } \\
\text { time }\end{array}$} & \multicolumn{3}{|c|}{ Incubation time (hours) } & \multirow[b]{2}{*}{ Regression equation } & \multirow[b]{2}{*}{$P$ value } \\
\hline & & 24 & 48 & 72 & & \\
\hline \multirow{3}{*}{ Vegetative } & 0 & 55.97 & 64.57 & 70.68 & $\begin{array}{c}Y=0.306 x+49.034 \\
R^{2}=0.9231\end{array}$ & $<0.0001$ \\
\hline & 4 & 53.11 & 62.83 & 68.61 & $\begin{array}{c}\mathrm{Y}=0.322 \mathrm{x}+46.02 \\
\mathrm{R}^{2}=0.9493\end{array}$ & $<0.0001$ \\
\hline & 7 & 51.49 & 60.74 & 66.26 & $\begin{array}{c}\mathrm{Y}=0.308 \mathrm{x}+44.728 \\
\mathrm{R}^{2}=0.9271\end{array}$ & $<0.0001$ \\
\hline \multirow{2}{*}{ Pre-Flowering } & 0 & 39 & 52.65 & 60.29 & $\begin{array}{c}\mathrm{Y}=0.443 \mathrm{x}+29.363 \\
\mathrm{R}^{2}=0.9516\end{array}$ & $<0.0001$ \\
\hline & 4 & 37.81 & 49.96 & 58.72 & $\begin{array}{c}Y=0.436 x+27.916 \\
R^{2}=0.9675\end{array}$ & $<0.0001$ \\
\hline Flowering & 0 & 25.49 & 34.1 & 41.42 & $\begin{array}{c}\mathrm{Y}=0.331 \mathrm{x}+17.738 \\
\mathrm{R}^{2}=0.947\end{array}$ & $<0.0001$ \\
\hline
\end{tabular}

$\mathrm{R}^{2}=$ Determination coefficient.

It should be considered the lignin content (Table 1) for the digestibility of NDF be mainly regulated by the content and type of lignin in the forage (OLIVEIRA et al., 2011; RICACHESKI et al., 2017), remaining explicit this rating in both vegetative and pre-flowering. Mutually, plants in full flowering also have low protein content, and this protein is less available because it is bound to lignin. By the progress on plant physiological cycle, there is a reduction in the crude protein content of 
forages, resulting in an increase in the proportion of stems and fiber contents as a reduction in the proportion of leaves (BRITO et al., 2003).

Along with the fibrous portion, the proportion of protein available to the microorganisms is a limiting factor for their proliferation and, therefore, bulk digestion. Protein digestion results largely in the ammonia production used by rumen microbiota as the main source for the microbial protein synthesis (COSGROVE et al., 2007; CRUZ et al., 2010; DIJKSTRA et al., 2012), and the speed of its use will be greater when soluble carbohydrates are available for the multiplication of these microorganisms.

The prolonged ryegrass dehydration process also affects the protein and soluble carbohydrate contents (Table 2), infering in less substrates for the entire digestion of silage. However, our results are contraditor by that found for Zamarchi et al. (2014), evaluating oats silage at final growth cycle, not reporting differences in IVTD for pre-drying technique, only between maturation stage.

The ruminal degradation curve presented a unequal behavior with the rising of productive cycle of ryegrass and also with the use of dehydration (Figure 1). The amount of DM disappeared per unit of time was decreasing from vegetative time 0 until flowering (2.29\% DM. ${ }^{-1}$ for vegetative and $1.19 \%$ DM. $\mathrm{h}^{-1}$ at flowering). We observed that the amount of DM degraded in the first incubation times has also variated. In the vegetative stage, most of the DM was degraded until the $48 \mathrm{~h}$, above all occurred until the $24 \mathrm{~h}$, when it usually occurs the lack of microbial adherence. So, in this stage, great part of these compounds is degraded faster.
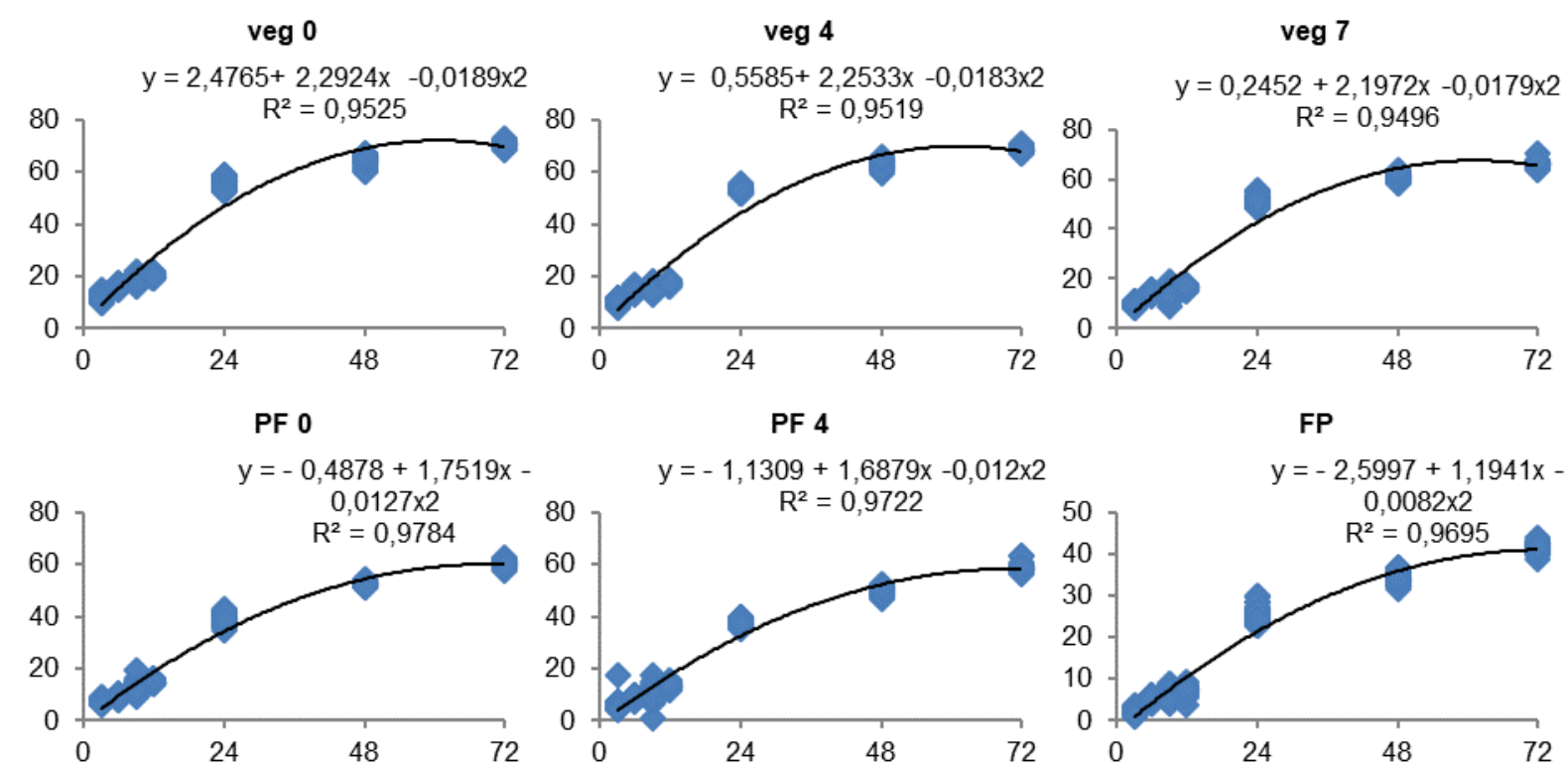

$\mathrm{X}$ axis $=$ time in hours; $\mathrm{Y}$ axis $=$ Degradation $(\%$ of the $\mathrm{OM})$.

Figure 1. In situ degradation curve ( 3 to 72 hours) of the ensiled biomass of annual ryegrass at distinct phenological growth stages and pre- dehydration times.

In the remaining stages, there is a higher concentration of structural carbohydrates and lignin, complicating factors of bulky, mainly because its comprise high variation in their nutritional composition as like as its rate of degradation of its components, varying according to forage species, plant age, time of year, fertilization and management of soil (KASUIYA et al., 2008; LIMA et al., 2012).

It can be observed in figure 2 that after 48 hours the degradability of all treatments tended to stabilize, however, the percentage of degraded material was dependent on the stage of plant development in which the ryegrass was ensiled.
With the increase of the NDF content, there is a decrease in the rate of degradation of DM (Figure 1) due to the difficulty of the rupture of these molecules by the bacteria, which affects, mainly, the rate of degradation. In general, this also affects the rate of passage of the feed because, the lower the rate of degradation, the longer the dwell feed retention time in the rumen, (MUNIZ et al., 2012; TOSTO et al., 2015).

The samples of the vegetative stage presented values superior to the others, mostly in the first three hours of incubation, agreeing to several authors report that younger plants have higher soluble carbohydrate contents such as starch and 
pectin, both rapidly digested in the rumen, even though pectin is part of the cell wall (PATTON, 1994; OLIVEIRA et al., 2013). This fact contributes to a better perspective for the use of temperate grasses in the feeding of the animals, demonstrating that the process is effective to maintain the fodder quality, a result that can be observed by the satisfactory results of the digestibility of the evaluated silage.

\section{CONCLUSIONS}

Vegetative stage with no pre-dehydration has a higher digestibility.
The digestibility of the ensiled ryegrass biomass was influenced by the dehydration times, just as plant growth stage, regardless of the methodology used.

Fiber and lignin contents were shown to be a limiting factor for ryegrass silage digestibility.

\section{ACKNOWLEDGMENT}

The authors express their gratitude to Brazilian Agricultural Research Corporation (EMBRAPA) for funding this research work.

RESUMO: O objetivo foi determinar como o tempo de emurchecimento e o ciclo da planta influenciam na digestibilidade in vitro e degradabilidade in situ da silagem de azevém. As amostras foram provenientes de experimento a campo, com delineamento experimental de blocos ao acaso, com seis tratamentos (Vegetativo: cortar e ensilar; cortar + pré-secagem de 4 horas e ensilar e; cortar + pré-secagem de 7 horas e ensilar. Pré-florescimento: cortar e ensilar e présecagem de 4 horas. Florescimento: cortar e ensilar) e quatro repetições. A armazenagem foi de quatro meses. Foram realizados três ensaios de digestibilidade in situ para determinar a degradabilidade ruminal em diferentes tempos (3, 6, 9, $12,24,48$ e 72 horas) e três ensaios de in vitro. A digestibilidade da silagem de azevém foi influenciada, tanto pelos tempos de desidratação, quanto pela idade da planta, sendo que, o tempo 0 do vegetativo apresentou alta proporção de componentes degradáveis, apresentando maior taxa de degradação até as 24 horas de incubação. A digestibilidade in vitro da silagem foi maior que degradabilidade in situ até às 48 horas. Maior digestibilidade da biomassa foi apresentada pelo tempo 0 do estádio vegetativo, para ambas as técnicas empregadas.

PALAVRAS-CHAVE: Degradação ruminal. Forragem hibernal. Lolium multiflorum. Nutrição de ruminantes. Silagem de pré-secado.

\section{REFERENCES}

ANTLE, J. M.; BASSO, B.; CONANT, R. T.; GODFRAY, H. C. J.; JONES, J. W.; HERRERO, M.; HOWITT, R. E.; KEATING, B. A.; MUNOZ-CARPENA, R.; ROSENZWEIG, C.; TITTONELL, P.; WHEELER, T. R. Towards a new generation of agricultural system data, models and knowledge products: Design and improvement. Agricultural Systems, v. 155; p. 255-268, 2017.https://doi.org/10.1016/j.agsy.2016.09.003 https://doi.org/10.1016/j.agsy.2016.10.002; https://doi.org/10.1016/j.agsy.2017.05.006

\section{A.O.A.C. ASSOCIATION OF OFFICIAL ANALYTICAL CHEMISTS Official methods of analysis of the} Association of Official Analytical Chemistry. 16a ed. Maryland, AOAC International, 1998.

\section{A.O.A.C. ASSOCIATION OF OFFICIAL ANALYTICAL CHEMISTS. Official methods of analysis of the Association of Official Analytical Chemistry.16 ed. Gaithersburg: AOAC International, 1997. 1298p.}

BALSALOBRE, M. A. A.; CORSI, M.; SANTOS, P. M.; PENATI, M. A.; DEMETRIO, C. G. B. Cinética da degradação ruminal do capim Tanzânia irrigado sob três níveis de resíduo pós-pastejo. Revista Brasileira de Zootecnia, v. 32, p. 1747-1762, 2003. https://doi.org/10.1590/S1516-35982003000700026 https://doi.org/10.1590/S1516-35982003000300003

BRITO, C. J. F. A.; RODELLA, R. A.; DESCHAMPS, F. C. Perfil químico da parede da parede celular e suas implicações na digestibilidade de Brachiaria brizantha e Brachiaria umidicola. Revista Brasileira de Zootecnia, v. 32, n. 8, p. 1835-1844, 2003. https://doi.org/10.1590/S1516-35982003000800005 
COSGROVE, G. P., BURKE, J. L., DEATH, A. F., HICKEY, M. J., PACHECO, D. AND LANE, G. A. Ryegrasses with increased water soluble carbohydrate: evaluating the potential for grazing dairy cows in New Zealand. Proceedings of the New Zealand Grassland Association, v. 69, p. 179-185, 2007.

CRUZ, B. C. C.; PORTELA, C. F.; CRUZ, C. L. S.; BITTENCOURT, D.; CRUZ, C. A. C. Metabolismo Ruminal: pH, N-NH , crescimento e eficiência microbiana. PUBVET, v. 4, n. 12, Ed. 117, Art. 790, 2010.

DIJKSTRA, J., ELLIS, J. L., KEBREAB, J. L., STRATHE, A. B., LÓPEZ, S., FRANCE, J.; BANNINK, A. Ruminal $\mathrm{pH}$ regulation and nutritional consequences of low $\mathrm{pH}$. Animal Feed Science and Technology, v. 172, p. 22-33, 2012. https://doi.org/10.1016/j.anifeedsci.2011.12.005

GOERING, H. K.; VAN SOEST, P. J. Forage fiber analysis (Apparatus, reagents, procedures and some applications). Washington, DC: USDA, 1970. (Agricultural Handbook, 379).

KASUYA, N.; XU, Q.; KOBAYASHI, Y.; FUKUDA, K.; ENISHI, O.; IIYAMA, K.; ITABASHI, H. Cell wall degradation of tropical and temperate forage grasses measured by nylon bag and in vitro digestion techniques. Animal Science Journal, v. 79, p. 200-209, 2008. https://doi.org/10.1111/j.1740-0929.2008.00518.x

KUNG, L. 2002. Subject: A review on silage additives and enzymes. Disponível em: //ag.udel.edu/anfs/faculty/kung/articles/a_review_on_silage_additives_and.htm. Acesso em: 20 de junho de 2015.

LIMA, M. L. M.; CASTRO, F. G. F.; AMARAL, A. G.; CARVALHO, E. R., NUSSIO, L. G.; MATTOS, W. R. S. Comparação da fibra em detergente neutro de forragens: desempenho, digestibilidade e parâmetros ruminais. Ciência Animal Brasileira, v. 13, n. 4, p. 450-459, 2012.

MACEDO JÚNIOR, G. L.; ZANINE, A. M.; BORGES, I.; PÉREZ, J. R. O. Qualidade da Fibra para ruminantes. Ciência Animal Brasileira, v. 17, n. 1, p. 7-17, 2007. https://doi.org/10.5216/cab.v13i4.19468

MARCHESAN, R.; PARIS, W.; TONION, R.; MARTINELLO, C.; MOLINETE, M. L.; DE PAULA, F. L. M.; ROCHA, R. Valor nutricional de cultivares de azevém consorciados ou não com aveia sob dois resíduos de pastejo. Revista de Ciências Agroveterinárias, v. 14, n. 3, p. 254-263, 2015.

https://doi.org/10.5965/223811711432015254

MARTINS, A. S.; VIEIRA, P. F.; BERCHIELLI, T. T.; PRADO, I. N.; CANESIN, R. C., SETTI, M. C. Taxa de passagem e parâmetros ruminais em bovinos suplementados com enzimas fibrolíticas. Revista Brasileira de Zootecnia, v. 35, n. 3, p. 1186-1193, supl., 2006. http://dx.doi.org/10.1590/S1516-35982006000400033

MUNIZ, E. B.; MIZUBUTI, I.Y.; PEREIRA, E. S.; PIMENTEL, P. G.; RIBEIRO, E. L.; PINTO, A. P. Cinética da fração fibrosa de volumosos para ruminantes. Revista Ciência Agronômica, v. 43, n. 3, p. 604610, 2012. https://doi.org/10.1590/S1806-66902012000300025

OLIVEIRA, A. S.; DETMANN, E.; CAMPOS, J. M. S.; PINA, D. S.; SOUZA, S. M.; COSTA, M. G. Metaanálise do impacto da fibra em detergente neutro sobre o consumo, a digestibilidade e o desempenho de vacas leiteiras em lactação. Revista Brasileira de Zootecnia, v. 40, n. 7, p. 1587-1595, 2011. http://dx.doi.org/10.1590/S1516-35982011000700026

OLIVEIRA, V. S.; SANTANA NETO, J. A.; VALENÇA, R. L. Características químicas e fisiológicas da fermentação ruminal de bovinos em pastejo - Revisão de literatura. Revista Eletrônica Científica de Medicina Veterinária, Garça - FAMED/FAEF e Editora FAEF. n.20, 2013.

PATTON, R. S. Complexities of soluble carboydrate metabolism in ruminants. Feedstuffs. Minneapolis, v. 66, n. 6, p. 13-19, 1994. 
RICACHESKI, S. T.; HENRIQUE, D. S.; MAYER, L. R. R.; OLIVEIRA, J. G.; ROSLER, J. A.; FLUCK, A. C. Chemical composition and ruminal degradation kinetics of white oat (Avena sativa L.) IPR 126. Revista Brasileira de Saúde e Produção Animal, v. 18, n. 1, p. 50-61, 2017. https://doi.org/10.1590/s151999402017000100006

ROMAN, J.; ROCHA, M. G.; PIRES, C. C.; MACARI, S.; PÖTTER, L.; ELEJALDE, D. A. G.; OLIVEIRA NETO, R. A.; KLOSS, M. G. Características produtivas e perdas de forragem em pastagem de azevém com diferentes massas de forragem. Revista Brasileira de Agrociência, v. 16, n. 1-4, p. 109-115, 2010.

SANTOS, N. L.; AZENHA, M. V., SOUZA, F. H. M.; REIS, R. A.; RUGGIERI, A. C. Fatores ambientais e de manejo na qualidade de pastos tropicais. Enciclopédia Biosfera, Centro Científico Conhecer - Goiânia, v.7, n. 13, p. 531-549, 2011.

SCHMIDT, P.; SOUZA, C. M.; BACH, B. C. Uso estratégico de aditivos em silagens: quando e como usar? In: JOBIM, C.C. Simpósio de conservação de forragens, Maringá, 2014.

SENGER, C. C. D. KOZLOSKI, G. V.; SANCHEZ, L. M. B.; MESQUITA, F. R.; ALVES, T. P.; CASTAGNINO, D.S. Evaluation of autoclave procedures for fiber analysis in forage and concentrate feedstuffs. Animal Feed Science and Technology. v. 146, p. 169 -174, 2008.

https://doi.org/10.1016/j.anifeedsci.2007.12.008

SILVEIRA, M. F.; KOZLOSKI, G. V.; MESQUITA, F. R.; FARENZENA, R.; SENGER, C. C. D.; BRONDANI, I. L. Avaliação de métodos laboratoriais para estimar a digestibilidade e o valor energético de dietas para ruminantes. Arquivo Brasileiro de Medicina Veterinária e Zootecnia, v. 61, p. 429-437, 2009. https://doi.org/10.1590/S0102-09352009000200021

SKONIESKI, F. R VIÉGAS, J.; BERMUDES, R. F.; NÖRNBERG, J. L.; ZIECH, M. F.; COSTA, O. A. D.; MEINERZ, G.R. Composição botânica e estrutural e valor nutricional de pastagens de azevém consorciadas. Revista Brasileira de Zootecnia, v. 40, n. 3, p. 550-556, 2011. https://doi.org/10.1590/S151635982011000300012

TOSTO, M. S. L.; ARAÚJO, G. G. L.; RIBEIRO, L. G. P.; HENRIQUES, L. T.; MENEZES, D. R.; BARBOSA, A.M.; ROMÃO, C.O. In vitro rumen fermentation kinetics of diets contain oldman saltbush hay and forage cactus, using a cattle inoculum. Arquivo Brasileiro de Medicina Veterinária e Zootecnia, v. 67, n. 1, p. 149-158, 2015. https://doi.org/10.1590/1678-6937

VAN SOEST, P. J.; ROBERTSON, J. B.; LEWIS, B. A. Methods for dietary fiber, neutral detergent fiber, and nonstarch polyssacarides in relation to animal nutrition. Journal of Dairy Science, v. 74, p. 3583-3597, 1991. https://doi.org/10.3168/jds.S0022-0302(91)78551-2

VANZANT, E. S.; COCHRAN, R. C.; TITGEMEYER, E. C.; STAFFORD, S. D.; OLSON, K. C.; JOHNSON, D. E.; ST JEAN, G. In vivo and in situ measurements of forage protein degradation in beef cattle. Journal of Animal Science, v. 74, p. 2773-2784, 1996. https://doi.org/10.2527/1996.74112773x

VELÁSQUEZ, P. A. T.; BERCHIELLI, T. T.; REIS, R. A.; RIVERA, A. R.; DIAN, P. H. M.; TEIXEIRA, I. A. M. A. Composição química, fracionamento de carboidratos e proteínas e digestibilidade in vitro de forrageiras tropicais em diferentes idades de corte. Revista Brasileira de Zootecnia, v. 39, n. 6, p. 1206-1213, 2010. https://doi.org/10.1590/S1516-35982010000600007

WILKINS, P. W.; HUMPHREYS, M. O. Progress in breeding perennial forage grasses for temperate agriculture. The Journal of Agricultural Science, v. 140, n. 2, p. 129-150, 2003.

https://doi.org/10.1017/S0021859603003058 
ZAMARCHI, G.; PAVINATO, P. S.; MENEZES, L. F. G.; MARTIN, T. N. Silagem de aveia branca em função da adubação nitrogenada e pré-murchamento. Semina: Ciências Agrárias, v. 35, n. 4, p. 2185-2196, 2014. https://doi.org/10.5433/1679-0359.2014v35n4p2185 